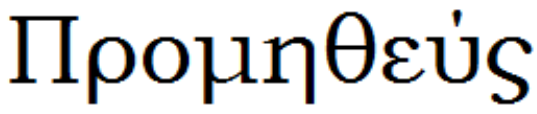

journal of philosophy

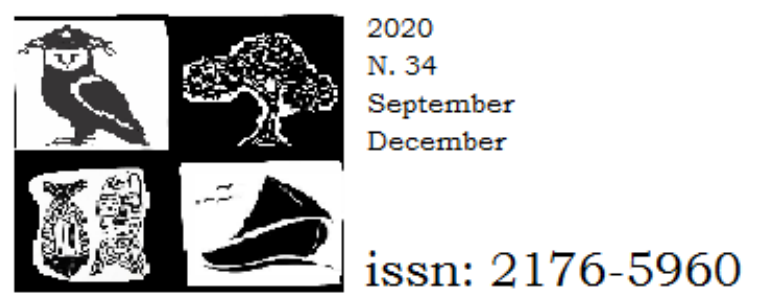

\section{A NATUREZA PERFORMÁTICA DO TIRANO}

\section{Jovelina Maria Ramos de Souza (Universidade Federal do Pará)}

RESUMO: Para tratar a questão da natureza performática do tirano, pretendo fazer alguns reconhecimentos da imagem do tirano entre a tragédia e a filosofia. A via investigativa proposta, se situa entre o Prometeu Acorrentado de Ésquilo e a República de Platão. O objetivo é mostrar a recepção do psiquismo tirânico de Zeus, ou mesmo de Prometeu, na caracterização do homem tirânico, em República IX.

PALAVRAS-CHAVE: Platão. Tirano. Tragédia. Filosofia.

ABSTRACT: In order to highlight the performative nature of the tyrant, I intend to make some acknowledgments of the tyrant's image between tragedy and philosophy. The investigative pathway that I propose is located between Aeschylus' Prometheus Bound and Plato's Republic. My aim is to show the reception of the tyrannical psyche of Zeus, or even of Prometheus, in the characterization of the tyrannical man in Republic IX.

KEYWORDS: Plato. Tyrant. Tragedy. Philosophy. 


\section{O poder nefasto de Eros}

A tragédia grega sempre foi o palco de manifestação de desejos tirânicos associados ao poder funesto de Eros e Afrodite. Observando o modo como os poetas trágicos representam as duas divindades do amor, Calame (2013, p. 146) caracteriza a desmesura própria de um psiquismo dominado pelos poderes de Eros e Afrodite, sob o epíteto de uma "tirania funesta", capaz de causar dor e sofrimento em quem se encontra sob seu jugo. Na estrutura performática da tragédia, percebe-se que o impulso provocado pelos dois deuses afeta intensamente a alma dos mortais, a ponto de desestruturá-la, como se pode observar no quarto estásimo do Hipólito de Eurípides:

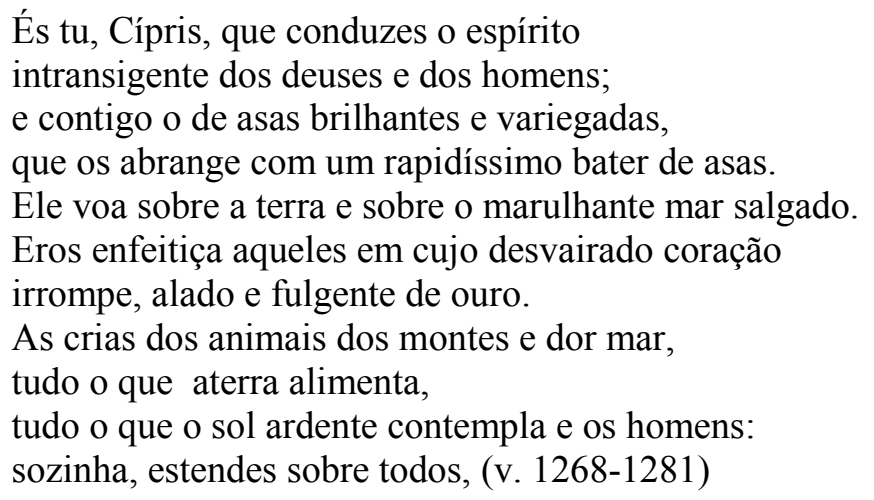

$\mathrm{Na}$ trama euripidiana, pode-se observar o resgate de uma representação recorrente na mélica arcaica, a de que o encantamento provocado por Eros e Afrodite, atordoa e suscita sofrimento. $\mathrm{Na}$ abertura da tragédia Hipólito, a deusa Cípria revela que, por seus desígnios, Fedra é tomada "por um amor avassalador (eroti deinoi)" (v. 28) direcionado a seu jovem enteado. Sob o efeito do encantamento despertado por Afrodite, a personagem é representada a partir de alguns paradigmas, que enfatizam sua figura como a de alguém afetada pelo desvario impulsionado pela divindade do amor. $\mathrm{Na}$ estrutura dramática da fala de Cípris, Fedra é descrita como alguém “apaixonada por um amor ausente" (v. 32). O desvario que a acomete, deixa-a atormentada sem ninguém saber a razão de tamanho sofrimento: "Mas agora a desgraçada, gemendo por ter sido ferida pelos ferrões do amor, definha em silêncio, sem que ninguém, lá em casa, tenha consciência de sua doença (noson)" (v. 38-40).

A imagem mais enfática do efeito nocivo do amor é apresentada pela própria Fedra, em tom confessional, às mulheres de Trezena (v. 392-402):

Quando percebi que estava apaixonada, pus-me a pensar na melhor maneira de aguentar o amor. Comecei a calar e a esconder a doença 
(noson). É que não vale a pena confiar na língua, que sabe aconselhar os pensamentos alheios dos homens, mas que seu próprio interesse só consegue grande quantidade de desgraças. Em segundo lugar, decidi aguentar dignamente esta demência (anoian), vencendo-a por um esforço de reflexão sensata (sophronein). Em terceiro lugar, visto que não era assim que conseguiria dominar Cípris, resolvi morrer; e ninguém negará que é a mais forte das decisões.

No lamento da personagem, Eurípides tanto associa o amor a uma doença, caracterizada como uma demência, quanto estabelece o contraponto entre tal patologia e a falta de sensatez. Neste sentido, o amor seria a causa da destruição da mulher de Teseu, e por associação, a de Hipólito, visto ser ele o alvo da vingança de Afrodite, não passando Fedra de um instrumento para a divindade atingir seu fim, como reforçam Fialho (2012, p. 28) e Lourenço (2012, p. 31). Na tragédia euripidiana, destaca Ragusa (2002/2003, p. 79), o poeta coloca em cena "a representação mais marcante e terrível de Afrodite", acrescido do fato de que no jogo cênico envolvendo cólera, paixão e morte, é a própria deusa quem expõe o seu plano de retaliação ao filho de Teseu, por venerar Ártemis e proferir injúrias contra ela. No Hipólito, ressalta a autora (p. 79), Cípris é caracterizada como "uma deusa violenta e impiedosa a proferir um discurso de vingança e desgraça". A caracterização da deusa Cípria com uma natureza vingativa e destruidora, reforça a imagem utilizada por Calame (2013, p. 148), para associar eros a um poder nefasto, capaz de causar infelicidade e ruína na alma dos amantes.

A natureza erótico-sexual do pathos emanado pela divindade de Chipre, se revela como uma potência selvagem e implacável, conforme ela própria ressalta, na abertura do prólogo (v. 1-9):

Grande e bem conhecido é meu nome entre os mortais e no céu sou a deusa Cípria. Respeito todos os que vêem a luz do sol entre o Mar Negro e os limites do Atlas, se veneram o meu poder, mas derrubo os que me desprezam. Pois também isto é próprio da raça dos deuses: gratifica-nos sermos venerados pelos homens. Mostrarei muito em breve a verdade destas palavras.

O alerta é dirigido a Hipólito, seguidor de Ártemis, que tanto renega Afrodite como manifesta repulsa aos prazeres do amor (v. 14-16) e às mulheres (v. 616-668). Fialho (2012, p. 27) destaca o fato de sua repulsa às paixões e aos prazeres do sexo, simbolizarem a rejeição à própria ordem da natureza, que torna possível a aproximação e a união entre os seres viventes, possibilitando a perpetuação da espécie. Ao contrário de Fedra, Hipólito é consciente de suas ações e de sua vontade, por mais arbitrária que 
ela venha a ser, como na manifestação desdenhosa à deusa, após o servo alertá-lo de sua falta de senso: “Quanto à tua Cípris... que passe bem!". (v. 113)

Já o arrebatamento de Fedra pelo impetuoso Hipólito, tramado ardilosamente por Cípris, escapa ao arbítrio da personagem, deixando-a completamente aturdida, ao se sentir coagida por uma indomável paixão, que demarca a incongruência, como defende Fialho (2012, p. 25), "entre a razão e os parâmetros ético-sociais a que está vinculada, por um lado, e a força da paixão que a arrasta para uma ação que não aprova", conduzindo-a à autodestruição. No relato às mulheres de Trezena, Fedra defende que o prazer (hedone) e o pudor (aidos) comportam uma natureza ambígua, "um não é mau; o outro é a ruína do lar”. (v. 385-386)

De maneira geral, o enredo da tragédia envolve a dicotomia entre a sensatez alegada por Hipólito, e a insensatez declarada por Fedra. Contudo, a arrogância do jovem, sua insistência em renegar os prazeres do sexo e as ofensas dirigidas a Afrodite, são traços de uma natureza que age de maneira irrefletida, e, portanto, contrária a imagem que constrói de si ao longo de sua narrativa; enquanto Fedra, mesmo sob o efeito de um impulso amoroso nefasto pelo enteado, se mostra sensata, como demonstra o final de sua fala às mulheres de Trezena (v. 420-430):

\begin{abstract}
Amigas, o que me mata é isto: que eu nunca seja surpreendida a desonrar o meu marido ou os filhos que dei à luz. Que possam viver, florescentes e livres de dizer o que quiserem, na ilustre cidade de Atenas, prestigiados por causa da mãe. Mesmo que seja de espírito corajoso, é escravo (douloi) o homem que vive na consciência das coisas vergonhosas praticadas pela mãe e pelo pai. Diz-se que na vida só concorre uma coisa: a posse de uma mente justa e boa. O tempo expõe, sem data avançada, os que são perversos dentre os mortais, como que pondo um espelho à frente de uma jovem virgem. Que eu nunca seja vista na sua companhia!
\end{abstract}

Como Calame, Lourenço (2012, p. 31) reforça a imagem da natureza destrutiva da paixão inspirada por Afrodite. $\mathrm{O}$ autor apresenta três características do caráter devastador das paixões, por ser capaz de causar danos irreparáveis tanto em quem as vivencia, como em quem é vítima de seus efeitos, quanto em quem precisa sobreviver ao cenário de morte e luto (id.). A cadeia destrutiva que envolve Fedra, Hipólito e Teseu, é, pois, exterior a eles próprios, sendo todos castigados pela afronta do jovem a Cípris. Conforme destaca o servo (v. 114-120), Hipólito age impetuosamente, "por ter as emoções à flor da pele". O efeito do caráter nefasto das paixões é ressaltado pelo coro, como um pathos que suscita agonia, sofrimento, "uma infeliz e nefasta 
incapacidade" (v. 163). É curiosa a analogia apresentada por Eurípides, entre as dores do parto e a loucura (aphrosynas) (v. 164), com a intenção de associar a agonia e o sofrimento, a um elemento que afeta especificamente a natureza instável das mulheres, embora seja Hipólito e não Fedra, a exceder os limites da falta de senso, em relação a Afrodite.

Entre o desejo de Fedra por Hipólito, e o apego de Hipólito a uma imagem de Ártemis projetada segundo seus próprios desejos, Eurípides defende que a paixão é nociva e afeta a estrutura do corpo e da alma. "A minha alma já está completamente arada pelo desejo" (v. 505), lamenta Fedra, expressando a manifestação do efeito nefasto de eros sobre ela; em contrapartida, Hipólito (v. 1001-1006) mostra ter a consciência do poder de Cípris, contudo a rejeita no sentido de fazer prevalecer a virgindade do corpo e da alma, pois segundo seus próprios parâmetros, afastar-se dos prazeres do amor, é o único modo de garantir a virtude (sophron). Lourenço (2012, p. 34) observa um aspecto muito interessante acerca da patologia de Fedra, mostrando como nos momentos de alucinação, a personagem não consegue controlar seu delírio, e seu desejo de unir-se ao objeto de seu amor, a levar a querer se fundir com ele. Levar a suplicante a abdicar de si, é o recurso utilizado pelo tragediógrafo para mostrar o estranhamento do amante diante das paixões que atormentam sua alma. Se por um lado, o suicídio de Fedra parece representar a cura de sua doença, por outro, resta o incômodo de saber que a força do amor, na sua dimensão mais nefasta, levou a personagem a desistir de si muito cedo.

\section{A natureza tirana de Eros}

Antevejo, na composição do discurso performático de Sócrates sobre o homem tirânico, em República IX, propondo-se a analisar, "qual é o seu carácter, e que espécie de vida leva, se desgraçada ou feliz" (571a), o esboço das ações desmedidas (hybris) delineadas nos protagonistas da tragédia Hipólito, de Eurípides, objeto da análise anterior, possibilita a delimitação do caráter funesto do amor, mas também permite pensar a natureza do pathos impulsionado por Eros e Afrodite, como um elemento que se instaura tiranicamente na estrutura psíquica dos amantes, abalando-a e causando sofrimentos, como entoa o terceiro estásimo da Antígona, de Sófocles: 


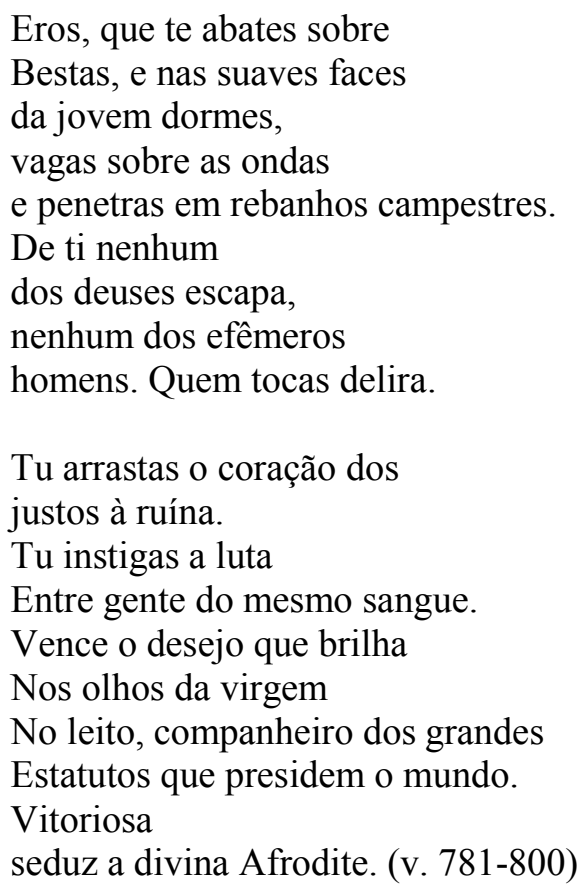

A inter-relação envolvendo as personificações de Eros e Afrodite, acentuadas no coro das tragédias Hipólito e Antígona, é marcada pela heterogeneidade, por resgatar o mito envolvendo os dois deuses, em que a figura de Eros, ora aparece como filho, ora como servidor de Afrodite. Calame (2013, p. 147-148) enfatiza como na ode ao Amor de Antígona, o impulso de Eros se direciona para uma força reconhecidamente mais potente, a natureza sedutora de Afrodite. Breitenberger reforça a associação entre eles, ressaltando que dentre os companheiros de Afrodite, Eros seria o único deus individualizado, estando em condição de igualdade para dividir com ela a personificação de divindade do amor. Breitenberger (2007, p. 3) aponta ainda a ascendência de Afrodite, sendo seu culto mais antigo e difundido que o de Eros. Segundo a autora (2007, p. 137), a "complexidade do nome do deus", parece ser resultante da extensa variedade de genealogias envolvendo seu nome. Platão, por exemplo, resgata algumas das representações de Eros firmadas pela tradição, em seis dos elogios do Banquete.

No coro das tragédias Hipólito e Antígona, Eurípides e Sófocles enfatizam a natureza tirana de Eros e Afrodite, representando-os como seres dotados do poder de desestruturar a constituição psicológica dos amantes. Neste sentido, o efeito "nefasto" de Eros e Afrodite, advém da ação das duas divindades sobre o psiquismo, ambas atuando como uma potência incontrolável, capaz de alterar o próprio modo de ser daquele que é afetado por seus poderes. Retomando o louvor ao amor da tragédia Hipólito, Calame (2013, p. 148) destaca: "Se o ser que destila o desejo pelos olhos pode 
inspirar os prazeres do amor à alma, lembremos que ele traz também o reverso da fortuna e da ruína". O poder nefasto de Eros, reafirmo, abala o psiquismo de Fedra, impulsionado pelos poderes de Afrodite, mas também o de Hipólito, dominado pelo seu extremado apreço a Ártemis.

A natureza antitética dos personagens trágicos, é um elemento amplamente trabalhado pelos tragediógrafos, no sentido de ressaltar o caráter ambíguo de seus heróis, movidos entre a sensatez e a insensatez, na defesa de seus valores, como Antígona e Creonte, Fedra e Hipólito, Prometeu e Zeus. Em Antígona, Hipólito e Prometeu Acorrentado, o embate entre modos distintos de agir ressalta a predominância da natureza funesta do poder de Eros e Afrodite, manifestado no enredo da trama, de modo "destrutivo e mortífero", como atribui Calame (2013, p. 146). O autor defende ainda que as personagens femininas das tragédias gregas seriam as maiores vítimas dos enfeitiçamentos amorosos suscitados por Eros e Afrodite. Vejo, contudo, que embora as mulheres sejam representadas como as principais vítimas dos arbítrios das divindades do amor, a dimensão psíquica dos personagens masculinos, também se mostra tiranizada, por se encontrar sob o efeito nefasto de afecções que se movem entre a pulsão de vida (eros) e a de morte (thanatos).

$\mathrm{Na}$ construção de seus personagens, os autores de tragédia retomam a caracterização da natureza ambígua dos personagens homéricos, revelada nas ações de confronto, em que se manifesta o desejo de escravizar o seu antagonista. O jogo de poder que envolve o drama trágico, mostra as distintas dimensões de desejos e prazeres na ordem dos discursos e das ações dos personagens. No caso da tragédia sofocliana, a rede de afetos que envolve Antígona, Hémon, Eurídice, comporta amor, desejo, amizade, enquanto a que envolve Creonte se direciona para o desejo de honra, de glória, de poder. Em Antígona, o antagonismo centralizado nos protagonistas da trama, longe de separá-los, os aproxima, posto que o embate entre Antígona e Creonte, representa o conflito comum a própria condição humana (STEINER, 1984 apud LOUREIRO, 2015, p. 56). No debate que antepõe a dualidade "homem e mulher, velhice e juventude, sociedade e indivíduo, vivos e mortos, humanos e deuses" (id.), os personagens dão mostras de um psiquismo escravizado, na defesa de seus valores.

No debate sobre o homem tirânico, Sócrates apresenta a metáfora do amor como "uma espécie de zangão enorme e alado" (573a), no sentido de mostrar que a estrutura de um psiquismo tirano é tiranizada por seus próprios desejos, de acordo com o desejo 
que é despertado nele, em determinadas situações, como nas práticas convivais, em que a dimensão apetitiva aflora, conforme se pode observar em 573a-b:

Por conseguinte, quando os demais desejos (epithymiai), a zumbir em volta do amor, repletos de incensos, de perfumes, coroas e vinhos e dos prazeres dissolutos de tais companhias, o fazem crescer e o alimentam até atingir o máximo e colocam neste aguilhão o zangão do desejo (pothos), é então que este protector da alma, escoltado pela loucura (manias), é tomado de frenesi (oistrai), e, se encontrar em si algumas opiniões ou desejos considerados honestos, mata-os e lançaos fora, para longe de si, até varrer da alma a temperança e a encher de uma loucura importada.

Na estrutura discursiva e performática dos protagonistas de Antígona, prevalece a dimensão do thymetikon e não a do epithymetikon, como na personagem Fedra. Inexiste em Antígona e Creonte, o desejo de conciliação, ou mesmo a intenção em fazer concessões, na defesa de seus valores. A falta de moderação é comum a ambos, dando mostras de que sua estrutura psíquica comporta uma natureza tirana. A rigidez do discurso proferido pela jovem e pelo ancião chega a ser destoante da causa que defendem. Observando o contexto ético-político que move a ação dos personagens, Pulquério (1987, p. 37) destaca, "no fundo, há um ponto em que se equivalem o tirano e a vítima: ambos agem com extrema rigidez, fautora do desastre".

Toda a ação performática dos personagens centrais da tragédia sofocliana, é marcada pela presença de um Eros tirano, que se manifesta por meio da fúria que os acomete e os perturba, levando Creonte a conceber que sua vontade está acima da dos homens por ele comandados, e até mesmo da dos próprios deuses, no seu ato de negar as honras fúnebres a Polinices. Por outro lado, o caráter destemido, ousado e indomável de Antígona, a impedem de temer a pena de morte imputada pelo próprio tio, por considerar as leis que ele representa, inferiores aos desígnios dos deuses. Diante do decreto de Creonte, Antígona não recua, não lamenta, tampouco acusa os deuses pelo destino funesto que lhe está reservado. A personagem, apesar de ter sido abandonada a própria sorte, se mantém fiel aos laços de sangue, não importando se isto lhe custe a própria vida, ao insistir em não abrir mão do desejo de perpetuar a memória do irmão.

A existência trágica de Antígona e Creonte, é marcada pelo caráter ambíguo de uma psykhe que escraviza, e ao mesmo tempo é escravizada. O caractere psíquico de alguém situado nesta condição dual, é variável, a ponto de estender seus desmandos aos deuses e aos homens, tamanha é a sede em concretizar seus desejos mais espúrios. Para ilustrar a natureza do homem tirânico, retomo a fala do personagem Sócrates em 
República 573c: "E assim é, meu caro, que o homem se torna rigorosamente um tirano, quando, por natureza, ou por hábito, ou pelos dois motivos, se torna ébrio (methystikos), apaixonado (erotikos) ou louco (melankholikos)". No contexto da filosofia platônica, a personificação da natureza ébria aparece na figura de Alcibíades. Na tragédia, Fedra representa a natureza erótica e melancólica ${ }^{1}$, enquanto Hipólito, a melancólica; já Antígona e Creonte, a melancólica, posto que a loucura que os move não é erótica, mas voltada para o desejo de glória, de honra, de defesa de valores (respectivamente, da tradição/família, das novas leis da cidade).

A contiguidade entre os personagens Antígona e Creonte, se dá a partir de um elemento norteador, o da natureza de um psiquismo caracterizado, seja por um caráter inflexível, seja pela incessante ausência de limites, aspectos valorizados por Platão em República IX, no processo de elaboração do caráter performático do homem tirânico, como a representação de uma estrutura psíquica tiranizada. Independente de qual seja a tipologia de desejo cultivada, a alma daquele que escraviza e, ao mesmo tempo, é escravizado, é habitada por um Eros tirano, funesto, que leva ao adoecimento, conforme ressalta Sócrates a seu interlocutor: "Logo, a alma tiranizada não fará de modo algum o que quer - refiro-me à alma na sua totalidade; mas, arrastada sempre à força por um desejo furioso, estará cheia de perturbações e remorsos" (577e). Seguindo a lógica do raciocínio socrático, a inquietação que atinge os protagonistas de Antígona, manifesta o desejo de saciar o desejo que os move, afligindo-os a ponto de se deixarem escravizar por suas vontades mais íntimas.

$\mathrm{Na}$ recepção da encenação do conflito que move o psiquismo de Antígona e Creonte, Platão demonstra que ambos estariam “[...] enlouquecido pelas paixões e por Eros" (578a), como é comum a todo indivíduo, cuja natureza é tirânica.

\section{Zeus tirano}

\footnotetext{
${ }^{1}$ Penso aqui na teoria dos humores de Hipócrates, que no tratado Da natureza do homem 4, afirma:

O corpo do homem tem dentro dele sangue, fleuma, bílis amarela e negra; esta é a natureza do corpo, através do qual adoece e tem saúde. Tem saúde, precisamente, quando estes humores são harmônicos em proporção, em propriedade e em quantidade, e sobretudo quando são misturados. O homem adoece quando há falta ou excesso de um desses humores, ou quando ela se separa no corpo e não se une aos demais [...]

Nesse sentido, a dor e o sofrimento resultam da desmesura, da falta de proporção entre cada um dos humores, causando o adoecimento de sua parte correspondente no corpo, correspondendo a natureza melancólica ao excesso de bílis negra no organismo; enquanto o colérico, a predominância da bílis amarela. Com isso, se pode conceber que no homem tirânico, a exemplo de Antígona e Creonte, predominam o temperamento colérico e o melancólico, que o leva a agir desarrazoadamente.
} 
A potencialização do poder tirano aparece na composição de Prometeu Acorrentado $^{2}$, onde Ésquilo esboça a imagem de um personagem invisível, mas potencialmente presente no discurso dos responsáveis por executar suas vontades arbitrárias. A abertura da tragédia posiciona em cena duas potências opressoras, cuja polaridade se concentra nas figuras, por um lado, de Kratos, manifestação da Dominação, do Poder, encarregado de exteriorizar os desígnios de seu senhor, e por outro, Bia, manifestação da Violência, da Força, expressa em atos e não em palavras ${ }^{3}$. Entre eles, o executor do castigo, Hefesto, que embora discorde da crueldade de Zeus tirano, vê-se se impedido de contrariar suas ordens, para não se confrontar com o que foi predeterminado em sua moira. Ressaltando o caráter onipresente e onipotente de Zeus, Poder recomenda ao deus artífice para não esboçar o menor sinal de hesitação, ou piedade, diante do ato infame que se vê obrigado a praticar, de modo a não suscitar a ira do novo governante do Olimpo.

A abordagem proposta não envolve a retomada integral da trama de Prometeu Acorrentado, dado a intenção de pontuar aspectos específicos da tragédia esquiliana, que sejam capazes de subsidiar a argumentação pretendida: a de observar a recepção do personagem Zeus, na tessitura do governante/homem tirano, ou mais objetivamente falando, da alma tirânica em República IX. Certamente que a chave argumentativa se situa na querela centrada por um lado, na figura de Zeus, o governante recém-chegado ao poder (v. 35) ${ }^{4}$, conforme anuncia Hefesto, sendo caracterizado pelo coro como alguém de "intocável (akikheta)/ caráter e coração impersuadível (aparamython)" (v. 184-185) $)^{5}$, que "com novas normas [...] exerce o poder", e por outro, o insolente Prometeu, que segundo o relato de Poder ao deus ferreito: "Teu adorno, brilho de artificioso fogo,/ Ele furtou e outorgou aos mortais" (v. 7-8), tendo que pagar por seu erro, para aprender a acatar "a tirania (tirannida) de Zeus/ e a abster-se de ser amigo (philanthropou) de humanos". (v. 10-11)

\footnotetext{
${ }^{2}$ Torrano traduz o título da tragédia por Prometeu Cadeeiro, embora utilize sua tradução, no uso corrente no texto, opto pela versão tradicional, Prometeu Acorrentado.

${ }^{3}$ Kratos e Bia tem um sentido similar, ambos podendo ser traduzidos por "poder" e "força". No jogo cênico de Prometeu Acorrentado, a diferença se estabelece na capacidade distinta de expressão: uma manifesta por meio de palavras e a outra por meio do silêncio, no entanto não se deve pensar o silenciamento como o abrandamento da intensidade da violência.

${ }^{4}$ Nos versos 33-35, Hefesto esclarece a Prometeu sobre a natureza colérica e inflexível de Zeus: "Muitos prantos e lamúrias inúteis/ balbuciarás, inexorável o ânimo (phrenes) de Zeus./ Todo áspero (trakhys) é quem tem recente o poder (kratei)".

${ }^{5}$ Prometeu responde ao coro, retomando o que lhe foi dito anteriormente por Hefesto: "Sei que é áspero (trakhys) e tem a justiça (dikaion)/ junto a si” (v. 186-187).
} 
Ressalto que na chave interpretativa que me proponho seguir, interessa-me mais especificamente a relação tirano-escravo, por entender que ela seja bem mais complexa que se possa imaginar, levando-me a atribuir que a base da estrutura tripartite do psiquismo na República, vai buscar subsídios na imagem do confronto entre um governante tirano e um governado resistente em se subordinar aos arbítrios de seu algoz.

A metáfora da relação tirano-escravo é determinantemente marcada pela ambiguidade. $\mathrm{Na}$ estrutura psíquica dos dois protagonistas da intriga esquiliana, o autor situa de um lado, a imagem do psiquismo tirânico e ao mesmo tempo tiranizado pelo desejo de vingança contra quem desafia seu poder, e do outro, a representação de um psiquismo escravizado e "submetido a tortura, como só os escravos podem ser" (VERNANT; VIDAL-NAQUET, 2002, p. 107), sem perder jamais a sua capacidade de resistência. Ésquilo amplia o grau de complexidade que envolve os dois personagens, pois embora Prometeu seja apresentado como escravo dos desejos de Zeus, também é inegável sua oposição a qualquer tipo de servilismo, elemento presente em sua crítica a Hermes, o escravo servil do tirano do Olimpo, defendendo enfaticamente: "Eu não trocaria, sabe-o claramente,/ minha dificuldade por tua servidão" (v. 966-967). Questionado pelo fiel mensageiro de Zeus, se seria melhor servir a uma pedra, responde enigmaticamente: “Assim se deve insultar (hybrizein) os insultantes (hybrizontas)" (v. 970), no caso aqueles que se deixam levar pela desmesura (hybris) e afligem sem justiça quantos se opuserem contra eles: "Falando simples, odeio a todos os deuses/ que bem tratados afligem-me sem justiça”. (v. 975-976)

No embate entre Prometeu e Hermes, Ésquilo amplia a ambiguidade do caráter do titã e o aproxima ainda mais de características pertinentes a Zeus, como a natureza tirânica. $\mathrm{O}$ vocabulário que sustenta o ácido diálogo entre eles, enfatiza a polaridade entre a noção de prudência, ou mais precisamente, a sua ausência, na caracterização da impulsividade de Prometeu, e elementos associados entre si como desmedida, delírio, desvario, doença, infortúnio, loucura. Aumentando ainda mais o caráter ambíguo dos protagonistas da intriga de Prometeu Acorrentado, o autor dota-os de um poder em comum, o dom da astúcia (metis), atributo capaz tanto de unir como separar, o imprudente Prometeu e seu cruel oponente. No confronto dialógico entre Hermes e Prometeu, a resistência do herói em não sucumbir ao poder de Zeus, se mostra na insistência em se negar a se deixar persuadir pelo discurso de seu opositor, aumentando a rivalidade (philonikia) entre ele e o senhor do Olimpo. 
No jogo cênico tecido por Ésquilo, o senhor dos deuses e dos mortais sente-se livre para punir cruelmente seus oponentes; enquanto o titã julga-se capaz de ludibriar a metis de seu opositor para beneficiar a humanidade, ambos cultivando o amor ao poder. O desejo de honra, de glória, aparece como um elemento predominante na estrutura psíquica de Zeus e Prometeu, que transparece tanto na crueldade do castigo como na arrogância elevada ao extremo, seja pela parte de Hermes seja pela de Prometeu, visto ambos acusarem-se mutuamente, no êxodo da tragédia, de se expressarem com soberba quando se dirigem um ao outro. Outro aspecto a ser destacado é o fato de Hermes manter uma relação assimétrica com Prometeu, emissário da palavra da divindade, ele se sente inferior a seu senhor, mas superior a quem considera seu escravo, exclamando (v. 999-1000): “Ousa, ó vaidoso (mataie), ousa finalmente,/ nas presentes dores, pensar de verdade (orthos phronein)". Seu contendor tanto lhe responde em tom de deboche como ignora o seu desejo de se impor, como se tivesse realmente o mesmo poder de Zeus (v. 1001-1006): "Bulhas em vão a falar-me como à onda./ Entenda-se que eu nunca por temer/ ânimo de Zeus me tornarei feminino/ nem suplicarei ao detestado inimigo/ imitando mulher, com mãos supinas,/ livrar-me destas cadeias. Longe disso!”.

A insolência de Prometeu o impede de julgar-se um suplicante, ele também não consegue se ver como uma divindade menor e subordinada a outra divindade, achandose no direito de confrontar as ordens de Zeus, enunciadas por seus fiéis mensageiros. A arrogância do titã, também é destacada na entrada em cena de Oceano, que o adverte:

Vejo, Prometeu, e quero aconselhar-te o mais útil, ainda que tu sejas solerte.

Conhece-te (gignoske sauton), e harmoniza com novos modos, novo é o tirano (tyrannos) entre os Deuses. (v. 307-310)

Por meio da advertência, Oceano o instiga a fazer uma revisão de sua postura, que envolve tanto o conhecimento de si como o reconhecimento de seu erro, ao se colocar contra os decretos divinos, para beneficiar a humanidade com o fogo roubado do Olimpo. A ambiguidade de Prometeu novamente é exposta, Ésquilo tanto o representa como um filantropo, como reforça a imagem de alguém que tomado pela hybris, não pondera antes de agir, embora tenha em si o dom da previsão. A representação de Prometeu como filantropo, é retomada por Platão no elogio de Aristófanes, no Banquete (189d), em que a imagem de Eros é associada "ao deus mais amigo do homem (theon philantropotatos), protetor e médico desses males, de cuja cura dependeria sem dúvida a maior felicidade para o gênero humano”. 
$\mathrm{Na}$ ação de Prometeu, que norteia todo o enredo da tragédia, pode-se antever, tanto os efeitos do Eros nefasto (kakos eros), que entorpece e arrebata, presente em Fedra, e retomado por Platão, no elogio de Pausânias ${ }^{6}$, reforçando o efeito nocivo de Eros e Afrodite Pandemos na estrutura psíquica, por ser desregrado e afastado de uma ação corretamente bela, como o cultivado por Afrodite e Eros Uranos. Mas Prometeu também é caracterizado como um philantropos $^{7}$, seu erro $^{8}$ foi provocado pelo amor desmedido pela humanidade e não para benefício próprio, como reforça para o coro: "Tudo isso eu bem conhecia./ Ciente, ciente errei (hemarton), não quero negar:/ ao socorrer mortais, descobri males" (v. 265-267), o que significa dizer que ao beneficiar os mortais, passaria a sofrer as mesmas dores e castigos humanos, como enfatiza ao coro: "Não supunha que com tais castigos/ ressecaria junto a pedras alcantiladas/ obtendo este ermo solitário penedo" (v. 268-270). De maneira similar a Prometeu, Zeus também errou ao aplicar tão severo castigo, reforçando sua caracterização como tirano “inflexível, injusto e ingrato" (SOTTOMAYOR, 2001, p. 135), cujo objetivo maior é perseguir e privar os mortais do fogo, assim como aplacar a hybris de Prometeu.

\section{O homem tirano}

No contexto do debate que proponho, defendo que na composição do homem tirano, Platão parece retomar a imagem de Zeus tiranizado por seu desejo de poder, para delimitar a estrutura psíquica do homem tirânico, em República IX, conforme assevera o personagem Sócrates: "uma alma tirânica é sempre forçosamente pobre e por saciar" (578a), além de ser assolada pelo temor. Mas quem é o tirano? O mais infeliz dos homens? Segundo Sócrates, o mais infeliz é: “Aquele que, sendo tirânico por natureza,

\footnotetext{
${ }^{6}$ Breitenberger (2007, p. 32) aponta que a distinção efetuada por Platão entre as duas Afrodites, em Banquete 180c-185c, recepciona a propagação do culto de Afrodite na Acrópole. No entanto, adverte a autora, "sua interpretação filosófica não parece refletir a natureza dos cultos reais". A controvérsia destacada por Breitenberger, repercute o fato de o filósofo classificar Afrodite Urânia, como a deidade responsável pelo amor "celestial"; e Afrodite Pandêmia, pelo amor "vulgar", voltado para a sexualidade. No entanto, nos rituais a Afrodite, Urânia encontra-se associada a reprodução e a fertilidade, enquanto Pandêmia é relacionada a um princípio político abstrato e a harmonia cívica.

${ }^{7}$ Gual (2003, p. 274) assinala, como desde a Antiguidade, a literatura recepciona o mito de Prometeu. Em Ésquilo, "o astuto deus tem se metamorfoseado no filantropo e rebelde patrão das artes humanas, frente a um Zeus tirano". O autor (2003, p. 275) destaca ainda como em Goethe e Shelley, ele se torna o "símbolo do revolucionário que busca a liberdade e a ilustração frente aos poderes do despotismo e da autoridade divina".

${ }^{8}$ Sottomayor (2001, p. 135) atribui que Prometeu comete uma hamartia voluntária, por ter a plena consciência de seu erro, além de já trazer inscrito na raiz de seu nome, o dom da "presciência". No livro III da Ética a Nicômaco, Aristóteles assevera que, “[...] é às paixões e ações voluntárias que se dispensa louvor e censura, enquanto as involuntárias merecem perdão e às vezes piedade [...]". $\mathrm{O}$ ato de Prometeu é considerado voluntário, pelo fato de ele não desconhecer o que pode lhe advir.
} 
não levar a vida de um particular, mas tiver a pouca sorte de, por qualquer acaso, lhe ser proporcionado alcançar a tirania" (578c).

Na construção da imagem do tirano, na República, Platão associa-o a um rico comerciante de escravos, que "[...] têm a semelhança com os tiranos de mandarem em muita gente. A diferença está no número" (578d). O homem tirânico, assim como o comerciante, tem a capacidade de agir de forma justa, no entanto os desejos ignóbeis que manifestam nas suas relações com os que lhes são subordinados, e até com eles mesmos, parecem assentadas no prazer de cometer atos injustos para satisfação de suas vontades, daí o homem cuja natureza é tirânica, ser representado como o mais infeliz dos homens, por não resguardar em si, o apreço pela justiça, desmerecendo que se o conceba como um homem justo ou feliz, porque predomina em sua natureza, por um lado, o impulso de cometer ações injustas, e por outro, o cultivo às paixões desmedidas, na sua prática de vida.

O paradigma do escravizador, em Prometeu Acorrentado, concentra-se em Zeus e seus comandados, Poder, Força, Hefesto, Oceano, Hermes, e o próprio coro, todos simbolizando o poder invisível e controlador do senhor do Olimpo. Na República, a ação performática do tirano, envolve aqueles que são escravizados por ele, a cidade e seus indivíduos, abrindo-se o debate para a escravidão individual do próprio tirano. Mas a maior evidência da presença de Zeus, na caracterização do tirano em República IX, encontra-se no questionamento de Sócrates (579a): “Ora bem! E se o deus estabelecesse em volta da casa dele muitos outros vizinhos, que não suportassem que alguém pretendesse mandar em outrem, mas, se apanhassem alguém com esses propósitos, lhe aplicassem a pena última?”. (579a)

A situação complicaria, uma vez que o tirano, a exemplo de Zeus, tiraniza quem se rebela contra ele. Todavia, não se pode deixar de levar em consideração, que o tirano também é tiranizado, nele habitam concomitantemente, temores e desejos de poder. $\mathrm{O}$ caráter performático como Sócrates apresenta a figura do tirano, o levam a descrevê-lo como alguém tomado por "gemidos, suspiros, lamentações e sofrimentos" (578a), como Prometeu, que relata seu drama a todos os seus interlocutores, sem, no entanto, se mostrar arrependido de sua falta para com os deuses. A grande questão que acompanha todo o imbróglio de Prometeu Acorrentado, é que nem Zeus nem Prometeu conseguem conciliar as suas afecções para encontrar um consenso. A tensão e não a moderação mostra-se presente na conduta dos dois personagens, nenhum deles cede a seus impulsos em todo o escopo da tragédia: Prometeu manifesta incessantemente sua cólera, 
enquanto Zeus não apresenta a intenção de perdoar o titã. A atitude de ambos fortalece o conflito e não a ordem. No perfil psicológico traçado por Ésquilo, eles conseguem atingir o ponto máximo da degeneração da alma, tornando-se escravos de seus próprios desejos.

Para Sócrates, o homem tirânico governa mal sua alma, sendo "forçado por qualquer acaso a ser tirano, e, sendo incapaz de se dominar a si mesmo, tenta mandar nos outros, como se uma pessoa doente e débil, em vez de estar em casa, fosse forçada a passar a vida a competir em força física" (579c-d), que a meu ver é o modo mais degradante de dominação do outro, o deixar suas marcas sobre ele, o apagar os seus vestígios, a sua honra, a sua glória, para reinar de forma soberana. O tirano não reconhece as diferenças, não se abre para o debate, porque sua alma deseja com o maior grau de intensidade, o combate, o conflito, a dissolução das diferenças, seja para manter o controle do poder seja para persuadir os seus opositores, por meio da força, da violência, da certeza de que ele realmente tem o poder absoluto, daí a necessidade de Ésquilo reforçar, por meio do relato de tantos personagens, o caráter aviltante de Zeus. Conforme destaca Sottomayor (2001, p. 136), em Prometeu Acorrentado, este estigma aparece "não só através dos impropérios do Titã e das justas lamentações da alucinada e inocente Io, mas também da hipocrisia bajuladora de Oceano, do servilismo sabujo de Hermes e da dureza inabalável do Poder".

Murray (2017, p. 200) ressalta que a figura do eros tirano é um tema amplamente retomado na tragédia, levando Platão a compor a imagem do tirano na República, com uma natureza surpreendentemente trágica, a que Marques (2011, p. 503) se refere como "a encenação política do tirano (do drama de sua ação)", em alusão ao passo $576 \mathrm{e}-577 \mathrm{~b}$, quando Sócrates questiona:

Seria porventura também justo solicitar as mesmas diligências em relação aos indivíduos, entendendo que só deve avaliá-los quem, em pensamento, for capaz de penetrar no caráter de um homem e ver claro nele, e não ficar fascinado como uma criança, que só vê a aparência, pela pompa majestosa que exibem para o mundo exterior, mas for suficientemente clarividente? Se, portanto, eu pensasse que devíamos todos escutar, aquele homem que é capaz de julgar, que conviveu na mesma casa com o tirano e que esteve presente nos actos de sua vida doméstica, na sua maneira de tratar com os familiares, entre os quais mais facilmente pode ser observado, despido do seu aparato teatral, e, bem assim, na ocasião de perigos públicos - se, depois de ele ter visto tudo isso, o incitássemos a proclamar o grau de felicidade ou de desgraça do tirano em comparação com os demais? 
No jogo cênico que envolve o discurso de Sócrates, é visível o antagonismo entre o olhar que se detém na aparência e o pensamento que é capaz de julgar. Paira na passagem, a hipotética possibilidade de que o espectador atento a realidade seria o próprio Platão, por sua convivência direta com um tirano real, Dionísio, em suas viagens a Siracusa. A questão é controversa, contudo o tom confidencial, é similar ao da Carta VII. Annas refuta a hipótese de que a personificação do tirano apresentada por Platão, como defendem alguns intérpretes, se referiria a um personagem histórico com quem Platão conviveu, Dioniso I de Siracusa ${ }^{9}$.

Por outro lado, Arruzza (2019, p. 53) defende que na performance do tirano platônico, é possível que Platão tenha resgatado traços, seja de Dionísio, o Velho, seja de Dionísio, o Jovem, a quem conheceu pessoalmente e observou seus modos de vida ${ }^{10}$. A autora mostra que na delimitação da natureza desregrada do tirano, o filósofo resgata elementos próprios do modo de agir de ambos, como a repressão aos inimigos (Dionísio, o Velho), os excessos eróticos e a libertinagem (Dionísio, o Jovem).

$\mathrm{Na}$ caracterização da figura do tirano, na teoria político-psicológica dos livros VIII e IX da República, Platão retoma sua experiência em Siracusa, demonstrada na Carta Sétima, para mostrar os riscos que a tirania, "a forma mais perversa de governo" (ARRUZZA, 2019, p. 53) representa, para a alma e para a cidade, desfavorecendo tanto a conduta individual (cidadão) como a coletiva (cidade), conforme se pode observar em 326a-b:

\begin{abstract}
Acabei por entender que todas as cidades de agora são mal governadas, pois têm legislação quase incurável, e falta uma preparação extraordinária aliada à fortuna. Fui obrigado a dizer, louvando a verdadeira filosofia (orthen philosophian), que a ela cabe discernir o politicamente justo (politika dikaia) em tudo dos indivíduos (idioton), e que a espécie dos homens não renunciará aos males antes que a espécie dos que filosofam correta e verdadeiramente chegue ao poder político, ou a espécie dos que têm soberania nas cidades, por alguma graça divina, filosofe realmente.
\end{abstract}

Novamente se estabelece a dicotomia, alma do homem-alma da cidade, agir individual-agir coletivo. Como na República, na Carta Sétima, a antinomia se

\footnotetext{
${ }^{9}$ Na nota 8 ao livro IX de sua tradução da República (1983, p. 419, Maria Helena da Rocha Pereira, assinala a hipótese aventada por alguns intérpretes, de que Platão seria "[...] o homem capaz de julgar [...]" (577b) o tirano, pelo fato de ter aceito o convite convivido pessoalmente com um tirano, Dionísio I de Siracusa.

${ }^{10}$ Platão foi três vezes a Siracusa, com intenção de ensinar filosofia ao governante, uma no reinado de Dionísio I (em 386 a.C.) e duas no de Dionísio II (em 366 a.C., retornando em 360 a.C.). A crítica a tirania é resultante de experiências não agradáveis, que o filósofo vivenciou no contato com os tiranos de Siracusa.
} 
estabelece entre as práticas de vida do homem que leva uma vida desgraçada, o tirano, e a do que supostamente levaria uma vida afortunada, por não se deixar escravizar pelas paixões desregradas. No relato sobre o tratamento dado pelo tirano a ele, Platão afirma que suportava as agruras, acreditando "que de algum modo ele pudesse chegar a desejar a vida do filósofo; mas ele venceu, resistindo-me". (330b)

No espetáculo encenado pelo tirano, suas máscaras vão caindo e seu verdadeiro caráter vai sendo mostrado: autoritário, maldoso, furioso, escravo de seus desejos e prazeres, infeliz, sempre agindo autoritariamente no seu espetáculo de horrores, o homem tirânico espalha maldade e infelicidade por onde passa, sendo a cidade regida por ele, a mais infeliz. Em República VIII 568a, Sócrates faz uma referência a Eurípides, embora o verso seja de Sófocles, do seguinte modo: "Porque é seu um dito, carregado de significado: 'Sábios são os tiranos pelo convívio com os sábios'. Evidentemente dizia sábios aqueles com quem os tiranos conviviam”. A alusão a Eurípides, na verdade comporta uma crítica ao elogio do poeta a tirania, em Troianas $^{11}$ e Fenícias $^{12}$. A despeito da ironia do poeta, a pretensão é colocar em evidência o quanto o desgoverno da alma do tirano, o leva a agir com desmandos, posto que internamente deseja veementemente, ser mais licencioso do que já é, se lhe fosse dado o direito de agir consonante com seus direitos, ele agiria entre os homens como se fosse um deus, não se poupando de invadir casas, de dormir com quem quisesse, de matar, de torturar, de libertar criminosos da prisão.

$\mathrm{Na}$ erótica platônica, a recepção do poder tirano de Eros atua como uma potência funesta. Elemento presente na tragédia, que Platão catalisa e ressignifica, reinserindo-a na República, como metáfora da natureza do homem tirânico e, ao mesmo tempo, tiranizado por seus desejos. A associação se firma na psicologia do livro IX da República, quando o filósofo retoma o debate apresentado no livro IV, de que o psiquismo se sustenta em uma estrutura tripartite, na qual predomina três tipos de desejos e prazeres associados a eles, que devem ser avaliados caso a caso, pois cada um

\footnotetext{
${ }^{11}$ Diante corpo de Heitor, em Troianas 1168-1170, Hécuba exclama:

Se tivesses morrido pela cidade, obtendo,

na juventude, bodas e tirania divinizante (isotheou tyrannidos), terias sido abençoado, se há nisso algo abençoado.

${ }^{12}$ Nos versos 521-525 de Fenícias, Etéocles se dirige a Jocasta, firmando sua intenção de não entregar o governo da cidade a Polinices:

Por isso, mova-se fogo, mova-se faca,

atrelai éguas, enchei o chão de carros, que não lhe entregarei minha realeza. Se devo ser injusto para ter a realeza, belíssima injustiça, venerável no mais.
} 
deles corresponde a uma determinada classe de homens: o amigo da sabedoria (philosophos), no qual predomina a dimensão intelectiva (logistikon); o amigo das honras (philothymos), movido pela dimensão impulsiva (thymetikon) e o amigo do lucro (philokerdes), tiranizado pela dimensão dos apetites (epithymetikon) (582a-583a).

No contexto de República IX, o movimento entre dimensões distintas de desejos, mostra o filósofo como o único capaz de vivenciar "a natureza do prazer que procede da contemplação do Ser" (582c). A distinção se centra no fato de a imagem do filósofo representar o paradigma de alguém que consegue administrar bem os seus impulsos, sem se tornar vítima do eros tirano, concebido como o tipo de desejo mais à margem da lei, por deixar predominar no psiquismo, durante o sono, não a dimensão reflexiva e mansa, mas a animal e selvagem, como se a estrutura psíquica estivesse livre e afastada do pudor e da sabedoria (571c). A natureza do filósofo, diferentemente da do tirano, cultiva o eros reflexivo, conforme se pode observar em 571d-572a:

\footnotetext{
Mas, em meu entender, quando uma pessoa, possuidora de saúde e de temperança só se entrega ao sono depois de ter despertado o seu raciocínio (to logistikon) e de o ter banqueteado com belos pensamentos e especulações, entregando-se à meditação interior, pondo de lado o desejo (to epithymetikon), sem ser por carência nem por excesso, a fim de ele adormecer e não causar perturbações, pela sua alegria ou pela sua tristeza, à parte melhor, e a deixa só, pura e independente, para observar e ansiar por perceber aquilo que ignora, do passado, do presente, ou do futuro
}

A metáfora é de uma beleza sem igual, e traduz a proposição de retomar a imagem de eros e associá-la, não mais a uma potência tirana, mas a figura do filósofo, cuja representação é marcada por um discurso, ao mesmo tempo, lógico e moderado. Acerca da passagem em questão, Annas (1981, p. 304) questiona se a caracterização do tirano é de fato pertinente, uma vez que o discurso performático de Sócrates, antepõe duas naturezas distintas, primeiro a imagem do que concebe como o mais infeliz dos homens, o de caráter tirânico; depois o filósofo, aquele que reflete para agir, sem se deixar dominar pelas paixões intempestivas, sendo por associação, sensato e feliz.

Para Annas, a metáfora não pode ser pensada como a personificação de um tirano real, devendo ser associada à representação de um estado psíquico dolorosamente adoecido, conforme o próprio Sócrates enuncia a Gláucon, “o homem que governa mal o seu íntimo, aquele que agora mesmo julgaste ser o mais desgraçado, o homem tirânico" (579c). Sendo o tirano um mau governante de sua própria estrutura psíquica, seu sofrimento é intenso e sua vida é penosa e injusta, visto ser 
o tirano autêntico um autêntico escravo, de uma adulação e servilismo extremo, lisonjeador dos piores; incapaz de satisfazer de algum modo os seus desejos, mostra-se muito carecido de quase tudo e pobre de verdade, se alguém conseguir contemplar a sua alma inteira, toda a vida cheio de medo, carregado de dores convulsivas. (579d-e)

Na concepção de Annas (1981, p. 305), apesar de a imagem do tirano ser concebida por meio de um discurso vigoroso, a estrutura interior do argumento exposto por Sócrates é frágil, levando-a a propor que, ao se deixar escravizar por seus desejos, o tirano se mostra inseguro e suscetível a ter seu poder tomado por aqueles que escraviza. Segundo a autora, a tese platônica de que no tirano, o senso se dissolve, é fraca e não convence, todavia, concebo que não se pode deixar de levar em consideração um pressuposto básico, a metáfora do homem tirânico não é meramente política e se insere em um contexto mais amplo, o de uma teoria psicológica, esboçada por Platão no livro IV, e plenamente desenvolvida em República IX, mostrando-se como base de sustentação da noção de alma tripartite. Considero que a recepção de um tirano real na composição da argumentação sobre a natureza tirânica do psiquismo, não invalida o debate proposto, mas antes delimita, ou até mesmo amplia, a percepção do leitor acerca da questão da tirania e seus efeitos na estrutura psíquica.

A delimitação da natureza performática do tirano, é um tema bastante controverso. Ao longo do texto segui algumas linhas interpretativas, que retomo agora, no sentido de concatenar com o que vem sendo apresentado, ao longo deste percurso. Annas (1981, p. 304) nega que o retrato do tirano, ricamente delineado por Platão, corresponda a figura de Dionísio I, no entanto concebe que se for procurar o caráter do tirano em um personagem histórico, se encontraria um correspondente, na figura de Calígula em seu desejo de atingir um poder absoluto, quebrando as convenções com seu exageros, extravagâncias e despudor ${ }^{13}$.

Arruzza (2019, p. 54), por sua vez, considera que embora na concepção do tirano, seja possível visualizar traços dos dois Dionísios, como a natureza vingativa e opressora de Dionísio, o Velho e o caráter lascivo e desregrado de Dionísio, o Jovem, cronologicamente seria impossível identificar o jovem Dionísio ao tirano de Platão. A autora introduz em sua análise, Thesleff e Meulder, no sentido de mostrar as

\footnotetext{
${ }^{13}$ A vida de Caio César Calígula, de Suetônio, demonstra o caráter tendencioso do autor, em descrever Calígula como alguém de natureza ambígua, em que parece prevalecer a índole má, sendo infeliz como o tirano platônico, conforme se pode observar nas seguintes passagens: "[...] que era o melhor dos criados e o pior dos senhores" ou "[...] Caio vive para sua infelicidade e a infelicidade de todos [...]" ou "[...] ele criava uma hidra para o povo romano e um Fetonte para o universo" (204).
} 
incongruências da tese que associa diretamente, o tirano e Dionísio, o Jovem. Concordando com Thesleff (2019, p. 55), ela acredita que a caracterização da psicologia do tirano, se integra com a crítica ao desregramento da dimensão dos apetites, aspecto que impossibilita a reformulação de sua postura moral.

Por outra perspectiva, Cairns (2017, p. 220) considera que a imagem (eikon) do tirano delineada por Platão, se mostra como a caracterização de um tipo de caráter desviante, cuja natureza comporta impulsividade, desejo de poder, prazer nos desmandos. Inegavelmente, o contexto do debate sobre o tirano é político, mas não se pode abstrair, como parece desejar Annas, a inter-relação com o discurso ético e psicológico que sustentam as teses de República VIII e IX (CAIRNS, 2017, p. 219), o que dá maior vivacidade a metáfora exposta por Sócrates, envolvendo a noção de alma tripartite. Antes de apresentar a metáfora, se observa o precioso cuidado do personagem Sócrates, em definir que se trata de uma imagem (eikon), e não de algo real (588b): "Modelemos em pensamento uma imagem da alma (eikona plasantes tes psykhes logoi), a fim de o autor daquelas palavras se aperceber do que disse".

Novamente, o recurso ao jogo linguístico para identificar aquele que constrói as imagens e sabe dar um justo sentido a elas. Na encenação da República, como nos demais diálogos platônicos, a face do filósofo se centra no paradigma daquele que sabe decifrar os meandres de um discurso que envolve imagem e reflexividade, posto ser capaz de direcionar seus desejos para a forma de vida "mais aprazível e mais isenta de desgosto" (581e-582a). Para Platão, o bom julgamento deve estar baseado "na experiência, na vigilância e no raciocínio" (582a), tarefa que somente o filósofo pode realizar, por se mover entre as variadas esferas de desejos, como se pode apreender em 582b: "Ele tem a necessidade de provar, a começar na infância, das outras espécies de prazer, ao passo que o interesseiro, se se dedicar a estudar as essências, não é forçoso que prove esse prazer, que saiba como é doce nem tenha disso experiência, nem de resto lhe é nada fácil, ainda que se esforce".

A expertise de Platão em tecer belas imagens que suscitam o exercício da reflexão, transpassa o final de República IX, com uma intensidade, capaz de deixar o leitor perplexo. Sua habilidade de fala, permite o reconhecimento de que não se trata apenas de fazer alusão a seres multiformes, como Quimera, Cila e Cérbero, mas de dar um sentido pleno a estas imagens, conforme pontua Sócrates a seu interlocutor (588c): "Modela então uma criatura monstruosa, compósita e policéfala, com cabeças de animais domésticos e selvagens, a toda a volta, e capaz de alterar, ou de criar por si, 
todas essas formas". Na imagem proposta, a psykhe é associada a um animal multiforme, "com uma forma única, a de um homem" (588e), a intenção é mostrar as variantes do comportamento humano, diante de determinadas situações.

A aparência de animal é um recurso utilizado pelos poetas, e que Platão recepciona na escrita de seus diálogos, para identificar a natureza selvagem do psiquismo, na manifestação do thymos. Se Aquiles é, para Homero, um thymoleon ${ }^{14}$, quem é o tirano? Quais são as suas máscaras? $\mathrm{Na}$ leitura que faço, direciono o acolhimento da natureza tirana, na discursividade da República, para os personagens da tragédia, como Antígona e Creonte, Fedra e Hipólito, Prometeu e Zeus, ou a do próprio Édipo, presente na manifestação dos sonhos daqueles cujas estrutura psíquica encontrase despida de qualquer "vergonha e reflexão" (571c-d). A República reúne uma variedade de imagens, que permite o reconhecimento de outras faces, ora de tiranos ora de naturezas tirânicas, que habitam o imaginário dos poetas trágicos, e devem ser pensadas como o paradigma de um psiquismo dominado por prazeres desregrados, o que de modo algum vem inviabilizar o projeto ético, político, pedagógico, psicológico, proposto por Platão na República.

\section{REFERÊNCIAS BIBLIOGRÁFICAS}

AMBROSIO, R. O tirano: entre a história e a tragédia. HYPNOS, n. 21, p. 231-244, $2^{\circ}$ semestre. 2008

ANNAS, H. Parts and Virtues of State and Soul. An Introduction to Plato's Republic. Oxford: Clarendon, 1981, p. 109-152.

AZAMBUJA, C. C. Prometeu: a sabedoria pelo trabalho e pela dor. Archai, Brasília, DF, n. 10, p. 19-28, jan-jul. 2013.

CAIRNS, D. The Tripartite Soul as Metaphor. In DESTRÉE, P.; EDMONDS III, R. G. Plato and the Power of Images. Leiden, Boston: Brill, 2017, p. 219-238.

CALAME, C. Eros na Grécia Antiga. Tradução Isa Etel Kopelman. São Paulo: Perspectiva, 2013.

CORNELLI, G.; SUSSUMO, M. O drama da doença: Tragédia e Medicina na Construção do Dramatis Personae platônicas. O que nos faz pensar, v. 26, n. 42, p. 6783, jan-jun. 2018.

DIXSAUT, M. Images du philosophe. Kleos, n. 4, p. 191-248. 2000.

\footnotetext{
${ }^{14}$ De coração de leão (Ilíada VII 228; Odisseia IV 724).
} 
EURÍPIDES. Tragédias II. Hipólito. Coordenação Maria de Fátima Sousa e Silva. Introdução, tradução e notas de Frederico Lourenço. Lisboa: Imprensa Nacional; Casa da Moeda, 2010, p. 11-93. . Teatro Completo, v. I. Tradução Jaa Torrano. São Paulo: Iluminuras, 2015. Teatro Completo, v. II. Tradução Jaa Torrano. São Paulo: Iluminuras, 2016.

GAZOLlA, R. A tirania na República - o outro em si mesmo. Rev. Filosofía Univ. Costa Rica, v. XLVI, n. 117/118, p. 87-93, enero-agosto. 2008.

HIPÓCRATES. Da natureza do homem. Tradução Henrique Cairus. In: CAIRUS, H. F.; RIBEIRO JR., W. A. Textos hipocráticos: o doente, o médico e a doença. Rio de Janeiro: FIOCRUZ, 2005, p. 39-59.

GUAL, C. G. Diccionario de Mitos. Madrid: Siglo Veintiuno de España, 2003.

MARQUES, M. P. A encenação do poder tirânico. Sobre República IX. In: PALUMBO, Lídia (A cura di) Lógon didónai. La filosofia come esercízio del render ragione. Studi in onore di Giovanni Casertano. Napoli: Loffredo Editore, 2011, p. 503525.

MOORE, C. Images of Oneself in Plato. In DESTRÉE, P.; EDMONDS III, R. G. Plato and the Power of Images. Leiden, Boston: Brill, 2017, p. 88-106.

MORGAN, K. A. Popular tyranny: sovereignty and its discontents in ancient Greece. Austin: University of Texas Press, 2003.

MURRAY, P. Poetry and the Image of the Tyrant in Plato's Republic. In DESTRÉE, P.; EDMONDS III, R. G. Plato and the Power of Images. Leiden, Boston: Brill, 2017, p. 199-218.

PLATÃO. A República. Introdução, tradução e notas de Maria Helena da Rocha Pereira. 4. ed. Lisboa: Calouste Gulbenkian, 1983.

Carta VII. Texto estabelecido e anotado por John Burnett. Introdução de Terence H. Irwin. Tradução e notas de José Trindade Santos e Juvino Maia Jr. Rio de Janeiro: PUC-Rio; São Paulo: Loyola, 2008.

O Banquete. Edição bilíngue. Tradução, posfácio e notas de José Cavalcante de Souza. São Paulo: Editora 34, 2016.

PLATON. La République. Traduction, introduction et notes Georges Leroux. Paris: GFFlammarion, 2002.

. Le Banquet. Tradcution, introduction et notes Luc Brisson. Paris: GFFlammarion, 1998. 
Lettres. Tradcution, introduction et notes Luc Brisson. Paris: GF-Flammarion, 1987.

SANTOS, A. O fogo de Prometeu: uma visão do mito a partir de conceitos da Filosofia de P. Ricoeur. Biblos, n. 1, p. 395-417. 2015.

SOTTOMAYOR, A. P. Q. O fogo de Prometeu. Humanitas, v. LIII, p. 133-140. 2001.

SUETÔNIO. A vida dos doze césares: Júlio César, Augusto, Tibério, Calígula, Cláudio, Nero, Galba, Óton, Vitélio, Vespasiano, Tito, Domiciano. Brasília: Senado Federal, Conselho Editorial, 2012. 